\section{International Scientific Journal Theoretical \& Applied Science}

p-ISSN: $2308-4944$ (print)

e-ISSN: 2409-0085 (online)

Year: 2016

Issue: 9

Volume: 41

Published: $30.09 .2016 \quad \underline{\text { http://T-Science.org }}$

SECTION 31. Economic research, finance, innovation, risk management.
A.Sh.Kupeshev

Doctor of economical science, professor, Kazakh Engineering and Pedagogical University of Nations Friendship

E.Turemuratov

Candidate of economical science, professor.,

Kazakh Engineering and Pedagogical University of Nations Friendship

Aigul Kuanyshevna Kupesheva

Candidate of economical science Chief of department of Kazakh Engineering and Pedagogical University of Nations Friendship

\section{Ersultan Zhomartovich Shalkhar} Muster student of Kazakh Engineering and Pedagogical University of Nations Friendship

Nurlan Muhtarovich Batyrbaev Candidate of law science, professor Vice president of International Kazakh-

Turkish University after H.A.Yessevi

Erkin Shazhievich Dusipov

Doctor of law science, professor Zhetysu state University after I.Zhansugurov

Yernar Sailaubekovich Shalkharov Master of law, economics, bachelor of biology. Corresponding member of Theoretical and Applied Science Academy. General director of BeinAgroIndustries LTD yernar_shalkharov@bk.ru

\title{
STALKING CLASSIFICATION INCHOATE CRIME IN RECOGNITION OF THREAT OF PURSUED LIFE AND HEALTH
}

\footnotetext{
Abstract: Today consideration process stalking as unfinished crime gains relevance. So called stalkers most often are the reason of unnatural behavior of the victim which can lead to deterioration in vital indicators including to disability for an accident cause. Having more psychological definition crime is reflected legally in offense of private space of the victim. At the same time from position of the criminal legislation of the Republic of Kazakhstan, that action isn't punished. Nevertheless, at the combined use of standards of the civil, criminal and administrative legislation and also at sequence correct use, progression of modern legal mechanisms, those actions aren't the inapplicable party of modern law.

Key words: crime, law, Kazakhstan.

Language: English

Citation: Kupeshev AS, Turemuratov E, Kupesheva AK, Shalkhar EZ, Batyrbaev NM, Dusipov ES, Shalkharov YS (2016) STALKING CLASSIFICATION INCHOATE CRIME IN RECOGNITION OF THREAT OF PURSUED LIFE AND HEALTH. ISJ Theoretical \& Applied Science, 09 (41): 156-158.

Soi: http://s-o-i.org/1.1/TAS-09-41-26 Doi: crossef http://dx.doi.org/10.15863/TAS.2016.09.41.26
}

\section{Introduction}

Dividing stalking into stages we can identify three stages of prosecution. All stages cardinally differ according to social behavioral characteristics, motives and extent of socially dangerous or personally dangerous act. So in stalking interest the 
stalker some characteristics of the victim observed. The personal sympathy, not shown aggression, certain level of an inclination, unexpressed offenses, debt and other reasons of dissatisfaction classified by the psychological legislation can be these characteristics (1).

\section{Materials and Methods}

First of all, stalker as a rule collects data of pursued. Existence of these data can be both public and personal (2). At the same time, receiving data of public character, the stalker violates nothing the rights and freedoms pursued as all received data are public element (3). However, practice shows that stalkers aren't limited to public data and generally pass line inquiring about personal data of the pursued object (4). At the same time it should be noted that obtaining data about pursued being public information isn't stalking. Respectively, any invasion into personal space of the victim is prosecution. Housing, some places of stay, habit, close people, secrets, the relations and other elements can be that private space (5).

The second stage of persecution assumes itself invasion of the stalker into private space pursued without knowledge of consent. The short distance visual analysis of objects of the private use pursued imperceptible observation, collection of information about pursued and theft of personal objects pursued can be that invasion (6). Most often those stalkers keep certain diary of observations for pursued where most often there is video, audio and photo record. These records received without the knowledge of the object or without appropriate sanction are an element of infringement of personal space in the criminal way. Also at this stage of prosecution there are trophies collected by the stalker from number stolen it the personal belongings which are thrown out by the victim (7). In the presence of those prosecution proofs, those physical evidences are good cause for involvement of the stalker to civil, administrative or criminal liability (8).

The third stage of prosecution is the persuasive behavior of the stalker without direct contact with the victim. That behavior most often is followed by phenomenon of moral decline of the victim because of fear of infliction of harm of life or to health that finally leads to victim reckless actions. At this stage stalkers become visible for the victim intentionally, for the purpose of threat. So, without expressing the motive in words and in actions, the stalker tries to obtain panic, as is the main instrument of infliction of harm to the victim. Deliberately appearing suddenly, gesticulating, in certain cases even threatening the victim, stalkers bring the victim out of psychological balance (9).

In the world literature stalkers are divided into six main types.

The first type of stalkers is kaves. The motive of the real stalkers is expressed in self-realization. Being been psychologically unsatisfied they as a rule leave business cards in public places, drawing certain signs or painting the pseudonyms on a review of the public (10).

The second type of stalkers is roleplayers. The motive of the real stalkers is expressed in simulation popular to the screen version of the film industry (11).

The third type of stalkers is intelligence agents. The presents find application in military, economic and industrial espionage (12).

The fourth type of stalkers is outcast. The persons unsatisfied or rejected in the relations with an opposite sex also are in the habit to pursue the victim (13).

The fifth type of stalkers is bouncers. As rule, they pursue debtors collecting information on their solvency with the purpose to have information that to require in compensation of damage (14).

The sixth type of stalkers is fans. Idealizing of certain person the persecutor can beat out pursued from stable condition (15).

\section{Conclusion}

Working in compliance with the specifics of behavior stalkers are in the habit to remove pursued from psychological balance that can lead to drawing to the health and life of pursued material and moral damage with risk of harm infliction. The present does stalkers by extremely dangerous segment of the persons who have committed an easy crime.

\section{Background.}

For a whole competent it is actual to notice that all issues in articles were formulated from the surveys of BeinAgroIndustries LTD. Also, it is important to mention together work of two university staff: Kazakh Engineering and Pedagogical University of Nations Friendship and International Kazakh-Turkish University after Khoga Akhmet Yassavi. In case of novelty, p.t.value the main author is the last in the list of authors.

\section{References:}




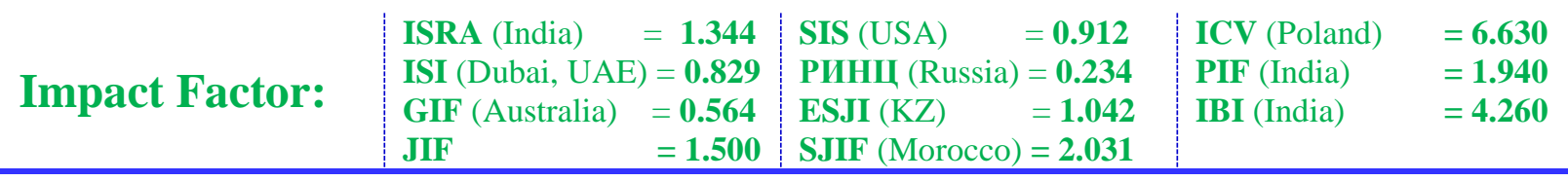

1. Joanne P. Smith-Darden, Dennis E. Reidy, Poco D. Kernsmith (2016) Adolescent stalking and risk of violence. Original Research Article. Journal of Adolescence, Volume 52, October 2016, Pages 191-200.

2. Britta Ostermeyer, Susan Hatters Friedman, Renee Sorrentino, Brad D. Booth (2016) Stalking and Violence. Review Article. Psychiatric Clinics of North America, In Press, Corrected Proof, Available online 6 August 2016.

3. Hucker SJ (2016) Forensic Psychiatry and Forensic Psychology: Stalking. Encyclopedia of Forensic and Legal Medicine (Second Edition), 2016, Pages 684-687.

4. Blanca E. Retana Franco, Rozzana Sánchez Aragón (2015) Acoso Cibernético: Validación en México del ORI-82. Original Research Article. Acta de Investigación Psicológica, Volume 5, Issue 3, December 2015, Pages 2097-2111.

5. Wayne Petherick (2014) 14 - Serial Stalking: Looking for Love in All the Wrong Places? Profiling and Serial Crime (Third Edition), 2014, Pages 295-317.

6. Brian H. Spitzberg, William R. Cupach, Annegret F. Hannawa, John P. Crowley (2014) A preliminary test of a relational goal pursuit theory of obsessive relational intrusion and stalking. Original Research Article. Studies in Communication Sciences, Volume 14, Issue 1, 2014, Pages 29-36.

7. Meloy JR ( 2013) Stalking. Encyclopedia of Forensic Sciences, 2013, Pages 202-205.

8. Felice Carabellese, Chiara Candelli, Donatella La Tegola, Egle Alfarano, Roberto Catanesi (2013) Female same gender stalking: A brief review of the literature and case report. Forensic Science International, Volume 228, Issues 1-3, 10 May 2013, Pages e6-e10.
9. Kristina Vogt, Elizabeth Hofer, Andreas Ryser, Mathias Kölliker, Urs Breitenmoser (2016) Is there a trade-off between scent marking and hunting behaviour in a stalking predator, the Eurasian lynx, Lynx lynx?. Original Research Article. Animal Behaviour, Volume 117, July 2016, Pages 59-68.

10. Laurence Miller (2012) Stalking: Patterns, motives, and intervention strategies. Review Article. Aggression and Violent Behavior, Volume 17, Issue 6, November-December 2012, Pages 495-506.

11. Kathleen A. Fox, Matt R. Nobles, Bonnie S. Fisher (2011) Method behind the madness: An examination of stalking measurements. Review Article. Aggression and Violent Behavior, Volume 16, Issue 1, January-February 2011, Pages 74-84.

12. Jacob Aron (2016) Stalking the radio blasts from the sky. New Scientist, Volume 229, Issue 3062, 27 February 2016, Page 12.

13. Haider $\mathrm{M}$ al-Khateeb, Gregory Epiphaniou (2016) How technology can mitigate and counteract cyber-stalking and online grooming. Original Research Article. Computer Fraud \& Security, Volume 2016, Issue 1, January 2016, Pages 14-18.

14. C. Vannucci, A. Delbreil, M. Sapanet (2013) Le stalking : nouvelle forme de harcèlement moral ? European Psychiatry, Volume 28, Issue 8, Supplement, November 2013, Page 82.

15. Harald Dressing, Peter Gass, Christine Kuehner. (2017) What can we learn from the first community-based epidemiological study on stalking in Germany? Original Research Article. International Journal of Law and Psychiatry, Volume 30, Issue 1, JanuaryFebruary 2007, Pages 10-17. 